\title{
DNA DAMAGE INDUCED BY OCCUPATIONAL EXPOSURE TO COPPER OXIDE NANOPARTICLES
}

\author{
${ }^{1}$ Pavel ROSSNER, 2Daniela PELCLOVA, ${ }^{1}$ Fatima ELZEINOVA, ${ }^{3}$ Pavel MIKUSKA, \\ ${ }^{3}$ Zbynek VECERA, ${ }^{3}$ Pavel COUFALIK, ${ }^{2}$ Stepanka VLCKOVA, ${ }^{2}$ Zdenka FENCLOVA, \\ ${ }^{1}$ Andrea ROSSNEROVA \\ ${ }^{1}$ Institute of Experimental Medicine, Czech Academy of Sciences, Prague, Czech Republic, EU, \\ pavel.rossner@iem.cas.cz, fatima.elzeinova@iem.cas.cz, andrea.rossnerova@iem.cas.cz \\ ${ }^{2}$ Charles University in Prague and General University Hospital in Prague, Prague, Czech Republic, EU, \\ daniela.pelclova@If1.cuni.cz, Stepanka.VIckova@vfn.cz, Zdenka.Fenclova@lf1.cuni.cz \\ ${ }^{3}$ Institute of Analytical Chemistry, Czech Academy of Sciences, Brno, Czech Republic, EU, \\ mikuska@iach.cz, vecera@iach.cz, coufalik@iach.cz
}

https://doi.org/10.37904/nanocon.2019.8653

\begin{abstract}
Copper oxide nanoparticles (CuO NPs) have a widespread use in industry, chemistry, in production of electronic devices and as an antimicrobial agent. Although copper is an important biogenic element, CuO NPs are toxic with the ability to induce oxidative stress, apoptosis, cell cycle arrest or DNA damage. For humans, the inhalation route is the most common way of exposure to CuO NPs. In the body, CuO NPs may be either deposited in the lungs, or transported to other organs. Their presence usually causes oxidative stress or inflammatory responses, consequently leading to DNA damage. In this study, we investigated the effect of $\mathrm{CuO}$ NPs inhalation on DNA damage in a group of researches conducting animal exposure experiments. The subjects were exposed to various metal oxide nanoparticles, including CuO NPs, by inhalation for an average of $4.9 \pm 0.4$ years. The average mass concentration of $\mathrm{Cu}$ in the air during the experiment was $7.3 \pm 3.2 \mathrm{ng} / \mathrm{m}^{3}$. Subjects not exposed to nanoparticles served as a control group. We applied micronucleus assay using Human Pan Centromeric probes to detect DNA damage and to distinguish between the frequency of centromere positive (CEN+) and centromere negative (CEN-) micronuclei (MN) in the binucleated cells. We did not find differences between both groups for either mean MN frequency (10.38 \pm 2.50 vs. $11.88 \pm 3.01$ $\mathrm{MN} / 1000$ binucleated cells), or $\mathrm{CEN}+/ \mathrm{CEN}-$ ratio $(58 \% / 42 \%$ vs. $55 \% / 45 \%)$, for the exposed and controls, respectively. In conclusion, inhalation of CuO NPs at this low-level exposure had no effect on chromosomal losses and/or breaks.
\end{abstract}

Keywords: Copper oxide nanoparticles, inhalation, DNA damage

\section{INTRODUCTION}

Copper oxide $(\mathrm{CuO})$ is commonly used in chemical industry for a production of various copper-containing materials (e.g. wood preservatives, dyes, ceramics), as well as in food industry and medicine as a dietary supplement. In its nano form, $\mathrm{CuO}$ is applied as an antimicrobial agent, in textile production or as a catalyst. Although copper is a biogenic element playing an important role as an enzyme cofactor, in the protection against infections, in tissue healing and bones development and growth, nano-CuO is potentially toxic and thus its interactions with biological systems should be investigated. Toxicity of CuO NPs is mostly related to reactive oxygen species (ROS) generation and resulting oxidative stress., although release of $\mathrm{Cu}$ ions from the surface of NPs also plays a role [1]. These processes may ultimately lead to cell death. While CuO NPs readily dissolve in culture media, particularly at the acidic environment, their solubility in water is limited. Thus, toxicity of CuO NPs is mostly mediated by the particles [2]. Compared to other metal-oxide NPs, toxicity of $\mathrm{CuO}$ is relatively high. This property is probably related to the ability of CuO NPs to overwhelm antioxidant defense systems of the organism [3]. 
In vitro studies on toxicity of CuO NPs were conducted in several cell lines and the results mostly indicated oxidative stress-related effects, including increased ROS production, lipid peroxidation, changes of glutathione levels, induction of $p 38$ and $p 53$ expression and modulation of autophagic response [2,4-6]. Apoptosis, another process initiated by ROS production, was also observed, along with cell cycle arrest, DNA damage, IL-8 production associated with induction of NF-KB pathway, selective membrane damage and interaction with proteins via hydrogen bonds potentially leading to changes in protein phosphorylation and ubiquitination [6-8]. $\mathrm{CuO}$ NPs have also been shown to affect histone methylation, expression of DNA repair proteins and interaction with cytoskeleton [6,9]. Whole genome gene expression analysis showed induction of genes involved in nucleic acids metabolic processes, response to stress, cell cycle, mitosis, cytokinesis, chromosome segregation, cellular component organization and morphogenesis. $\mathrm{Cu}$ ions alone induced expression of superoxide dismutase 2 and genes encoding metallothionein isomers [2].

In experimental animals, most of the studies focused on pulmonary effects of CuO NPs exposure usually finding inflammatory responses, changes in levels of antioxidants, acute cell death or cytotoxicity [3,10-13]. Effects of $\mathrm{CuO}$ NPs inhalation on whole genome transcriptional changes in rats revealed deregulation of hundreds of genes, but this number significantly dropped after a recovery period. The main processes affected by the exposure included cell proliferation/survival and inflammation; no effects on oxidative stress related pathways were found [14]. The current animal data further indicate neurotoxic effects of CuO NPs manifested by altered function of blood-brain barrier, damaged neurons and brain edema, chromatin congregation and mitochondria shrinkage in olfactory cells, or increase of endoplasmic reticulum and disassociation of ER ribosomes in hippocampus $[1,15,16]$.

A number of studies investigating negative health effects of CuO NPs exposure in humans is very limited. In an in vitro study, lymphocytes obtained from blood of healthy volunteers were treated with CuO NPs. In the cells, increased ROS production along with mitochondrial and lysosomal damage was detected [17]. To study negative health effects of wood preservatives containing $\mathrm{CuO}$ NPs, quantitative (probabilistic) human health risk assessment was performed. The results revealed inhalation risks from $\mathrm{CuO}$ in workers handling dry powders and performing sanding operations. There were, however, substantial uncertainties in these results stemming mainly from the extrapolation from short to long-term exposure, which was necessary due to the lack of (sub)chronic in vivo studies [18].

In the present study we investigated the effect of CuO NPs exposure in researchers performing animal experiments in which these NPs were used for whole-body inhalation [19]. A group of researchers not working with NPs served as controls. We aimed to assess potential DNA damage associated with the exposure.

\section{METHODS}

\subsection{Study groups}

The exposed group $(\mathrm{N}=8)$ consisted of researchers working with rodents exposed to $100 \%$ engineered nanoparticles (primarily to $\mathrm{CuO}$ in the last 13 weeks, preceded by exposures to $\mathrm{MnO} \times \mathrm{Mn}_{2} \mathrm{O}_{3}, \mathrm{CdO}, \mathrm{PbO}, \mathrm{TiO}_{2}$ and $\mathrm{ZnO}$ ). The average mass concentration of $\mathrm{Cu}$ in the air during experiments was $7.3 \pm 3.2 \mathrm{ng} / \mathrm{m}^{3}$. The controls $(\mathrm{N}=8)$ were a matched group of researchers not exposed to NPs.

\subsection{Cytogenetic analysis}

Blood samples: Blood cell cultures were incubated at $37^{\circ} \mathrm{C}$ for $72 \mathrm{~h}$. Cytochalasin $\mathrm{B}$ was added to a final concentration of $5 \mu \mathrm{g} / \mathrm{ml}$ after $44 \mathrm{~h}$. Cultures were harvested by centrifugation, treated with hypotonic solution of $\mathrm{KCl}$ and fixed with methanol/acetic acid. 
Centromeric FISH technique: The protocol performed with FITC-labelled Human Pan Centromeric probes was adapted from the manufacturer protocol (Cambio, Cambridge, UK). Stained slides were counterstained with DAPI mixed with Vectashield mounting medium [20].

Microscopic analysis: One thousand binucleated cells (BNC) were analyzed for each subject under the fluorescence microscope (Axioskop - Zeiss) equipped with filters for DAPI (blue signal) and FITC (green signal). BNC with micronuclei $(\mathrm{MN})$, centromere positive $(\mathrm{CEN}+)$ and centromere negative (CEN-), were recorded and analyzed by use of the ISIS software version 5.0 (MetaSystems).

\subsection{Statistical analysis}

Basic descriptive statistics [mean, standard deviation (SD), minimum and maximum], were calculated using Microsoft Excel 2013. T-test and the Wilcoxon signed-rank test were used for the comparison of the studied parameters (total MN/1000 BNC, CEN+ MN/1000 BNC and CEN- MN/1000 BNC).

\section{RESULTS AND DISCUSSION}

The characteristics of the studied groups are summarized in Table 1. The groups were matched by age and $\mathrm{BMI}$, but there was a greater proportion of men than women in the exposed group. All study subjects were nonsmokers. The exposed subjects have been conducting animal experiments with NPs for $4.9 \pm 0.4$ years (mean \pm SD). Before collection of blood samples, the researchers have worked solely with CuO NPs for 13 weeks. The average total time \pm SD of exposure to CuO NPs in this period was estimated to be $569.9 \pm 316.5$ $\min$.

The results of cytogenetic analyses are reported in Table 2. The frequency of MN/1000 BNC $(10.38 \pm 2.50 \mathrm{vs.}$ $11.88 \pm 3.01)$, percentage of aberrant cells $(0.98 \pm 0.23$ vs. $1.08 \pm 0.27)$ and proportion of CEN+/CEN- MN (58/42 vs. 55/45) did not differ between the exposed and controls subjects. These findings suggest that exposure of researchers to CuO NPs that occurs during animal experiments has no impact on DNA damage. This observation may be explained by very low concentrations of NPs in the working environment as well as by a short time of exposure distributed over a relatively long period (a maximum of 16 hours of exposure for 13 weeks). These factors may contribute to possible elimination of DNA damage by repair processes. We should further mention that in the last 5 years the study subjects had been continuously exposed also to other NPs. This implies that: 1 . The response of the organism can be attributed not only specifically to CuO NPs exposure, but also potentially to the effect of other compounds; 2. long-term exposure to NPs may have induced adaptation in the exposed subjects which was manifested by the lack of genotoxic effects [21]. Such adaptation was observed in our recent study of NPs-exposed workers [20]. Finally, we should mention a small sample size and unequal gender distribution between the exposed and control subjects which may have contributed to negative results in our study. A larger study group could yield possibly more reliable results with greater statistical power.

Table 1 Characteristics of the studied groups [N or mean \pm SD (min-max)]

\begin{tabular}{|l|c|c|}
\hline Characteristics & Exposed & Controls \\
\hline Number (N) & 8 & $4 / 4$ \\
\hline Males/Females (N) & $6 / 2$ & $41.6 \pm 12.6(26-64)$ \\
\hline Age (years) & $43.0 \pm 16.0(28-67)$ & $23.3 \pm 3.1(18.1-27.4)$ \\
\hline BMI (kg/m $\left.{ }^{2}\right)$ & $25.2 \pm 4.6(19.5-33.3)$ & 0 \\
\hline Smoking (N) & 0 & 0 \\
\hline Total exposure to CuO NPs (min) & $569.9 \pm 316.5(70-961)$ & 0 \\
\hline Working with NPs (years) & $4.9 \pm 0.4$ & \\
\hline
\end{tabular}


Table 2 The results of cytogenetic analyses in the subjects exposed to CuO NP and in the controls (mean \pm $\mathrm{SD}$ or \%)

\begin{tabular}{|l|c|c|c|c|}
\hline & $\mathbf{N}$ & MN/1000 BNC & \% AB.C. & CEN+/CEN- (\%) \\
\hline Exposed & 8 & $10.38 \pm 2.50$ & $0.98 \pm 0.23$ & $58 / 42$ \\
\hline Controls & 8 & $11.88 \pm 3.01$ & $1.08 \pm 0.27$ & $55 / 45$ \\
\hline
\end{tabular}

\section{CONCLUSION}

In our study, we did not find any genetic damage in researchers working with $\mathrm{CuO}$ and other nanoparticles. Our observations may be explained by low exposure levels over a long period of time, adaptation to NPs exposure and a small sample size. To confirm the results, a larger study is required.

\section{ACKNOWLEDGEMENTS}

\section{Supported by MEYS CR (L01508), Grant Agency of CR (18-02079S), Progres Q25/LF1 and Q29/LF1.}

\section{REFERENCES}

[1] MAGAYE, R., ZHAO, J., BOWMAN, L., DING, M. Genotoxicity and carcinogenicity of cobalt-, nickel- and copperbased nanoparticles. Exp. Ther. Med. 2012. vol. 4, no. 4, pp. 551-561. https://doi.org/10.3892/etm.2012.656.

[2] HANAGATA, N., ZHUANG, F., CONNOLLY, S., LI, J., OGAWA, N., XU, M. Molecular Responses of Human Lung Epithelial Cells to the Toxicity of Copper Oxide Nanoparticles Inferred from Whole Genome Expression Analysis. ACS Nano. 2011. vol. 5, no. 12, pp. 9326-9338. https://doi.org/10.1021/nn202966t.

[3] AHAMED, M., AKHTAR, M.J., ALHADLAQ, H.A., ALROKAYAN, S.A. Assessment of the lung toxicity of copper oxide nanoparticles: current status. Nanomedicine (Lond.). 2015. vol. 10, no. 15, pp. 2365-2377. https://doi.org/10.2217/nnm.15.72.

[4] KARLSSON, H.L., CRONHOLM, P., GUSTAFSSON, J., MÖLLER, L. Copper Oxide Nanoparticles Are Highly Toxic: A Comparison between Metal Oxide Nanoparticles and Carbon Nanotubes. Chem. Res. Toxicol. 2008. vol. 21, no. 9, pp. 1726-1732. https://doi.org/10.1021/tx800064j.

[5] WANG, Z., LI, N., ZHAO, J., WHITE, J.C., QU, P., XING, B. CuO Nanoparticle Interaction with Human Epithelial Cells: Cellular Uptake, Location, Export, and Genotoxicity. Chem. Res. Toxicol. 2012. vol. 25, no. 7, pp.15121521. https://doi.org/10.1021/tx3002093.

[6] CHIBBER, S., SHANKER, R. Can CuO nanoparticles lead to epigenetic regulation of antioxidant enzyme system?: CuO NPs can result in epigenetic regulation: a hypothetical view. J. Appl. Toxicol. 2017. vol. 37, no. 1, pp. 84-91. https://doi.org/10.1002/jat.3392.

[7] KUNG, M.-L., HSIEH, S.-L., WU, C.-C., CHU, T.-H., LIN, Y.-C., YEH, B.-W., HSIEH, S. Enhanced reactive oxygen species overexpression by $\mathrm{CuO}$ nanoparticles in poorly differentiated hepatocellular carcinoma cells. Nanoscale. 2015. vol. 7, no. 5, pp. 1820-1829. https://doi.org/10.1039/C4NR05843G.

[8] RABBANI, G., KHAN, M.J., AHMAD, A., MASKAT, M.Y., KHAN, R.H. Effect of copper oxide nanoparticles on the conformation and activity of $\beta$-galactosidase. Colloids Surf. B Biointerfaces. 2014. vol. 123, pp. 96-105. https://doi.org/10.1016/j.colsurfb.2014.08.035.

[9] CHENG, T.F., CHOUDHURI, S., MULDOON-JACOBS, K. Epigenetic targets of some toxicologically relevant metals: a review of the literature. J Appl Toxicol. 2012. vol. 32, no. 9, pp. 643-53. https://doi.org/10.1002/jat.2717.

[10] YOKOHIRA, M., HASHIMOTO, N., YAMAKAWA, K., SUZUKI, S., SAOO, K., KUNO, T., IMAIDA, K. Lung Carcinogenic Bioassay of $\mathrm{CuO}$ and TiO2 Nanoparticles with Intratracheal Instillation Using F344 Male Rats. J. Toxicol. Pathol. 2009. vol. 22, no.1, pp. 71-78. https://doi.org/10.1293/tox.22.71. 
[11] YOKOHIRA, M., KUNO, T., YAMAKAWA, K., HOSOKAWA, K., MATSUDA, Y., HASHIMOTO, N., SUZUKI, S., SAOO, K., IMAIDA, K. Lung Toxicity of 16 Fine Particles on Intratracheal Instillation in a Bioassay Model Using F344 Male Rats. Toxicol. Pathol. 2008. vol. 36, pp. 620-631. https://doi.org/10.1177/0192623308318214.

[12] CHO, W.-S., DUFFIN, R., POLAND, C.A., HOWIE, S.E.M., MACNEE, W., BRADLEY, M., MEGSON, I.L., DONALDSON, K. Metal oxide nanoparticles induce unique inflammatory footprints in the lung: important implications for nanoparticle testing. Environ. Health Perspect. 2010. vol. 118, no. 12, pp. 1699-1706. https://doi.org/10.1289/ehp.1002201.

[13] GOSENS, I., CASSEE, F.R., ZANELLA, M., MANODORI, L., BRUNELLI, A., COSTA, A.L., BOKKERS, B.G.H., DE JONG, W.H., BROWN, D., HRISTOZOV, D., STONE, V. Organ burden and pulmonary toxicity of nano-sized copper (II) oxide particles after short-term inhalation exposure. Nanotoxicology. 2016. vol. 10, no. 8, pp. 10841095. https://doi.org/10.3109/17435390.2016.1172678.

[14] COSTA, P.M., GOSENS, I., WILLIAMS, A., FARCAL, L., PANTANO, D., BROWN, D.M., STONE, V., CASSEE, F.R., HALAPPANAVAR, S., FADEEL, B. Transcriptional profiling reveals gene expression changes associated with inflammation and cell proliferation following short-term inhalation exposure to copper oxide nanoparticles. $J$. Appl. Toxicol. 2018. vol. 38, no. 3, pp. 385-397. https://doi.org/10.1002/jat.3548.

[15] MIGLIORE, L., UBOLDI, C., DI BUCCHIANICO, S., COPPEDĖ, F. Nanomaterials and neurodegeneration: Nanomaterials and Neurodegeneration. Environ. Mol. Mutagen. 2015. vol. 56, no. 2, pp. 149-170. https://doi.org/10.1002/em.21931.

[16] LIU, Y., GAO, Y., LIU, Y., LI, B., CHEN, C., WU, G. Oxidative stress and acute changes in murine brain tissues after nasal instillation of copper particles with different sizes. J. Nanosci. Nanotechnol. 2014. vol. 14, no. 6, pp. 4534-4540.

[17] ASSADIAN, E., ZAREI, M.H., GILANI, A.G., FARSHIN, M., DEGAMPANAH, H., POURAHMAD, J. Toxicity of Copper Oxide (CuO) Nanoparticles on Human Blood Lymphocytes. Biol. Trace Elem. Res. 2018. vol. 184, no. 2, pp. 350-357. https://doi.org/10.1007/s12011-017-1170-4.

[18] HRISTOZOV, D., PIZZOL, L., BASEI, G., ZABEO, A., MACKEVICA, A., HANSEN, S.F., GOSENS, I., CASSEE, F.R., DE JONG, W., KOIVISTO, A.J., NEUBAUER, N., SANCHEZ JIMENEZ, A., SEMENZIN, E., SUBRAMANIAN, V., FRANSMAN, W., JENSEN, K.A., WOHLLEBEN, W., STONE, V., MARCOMINI, A. Quantitative human health risk assessment along the lifecycle of nano-scale copper-based wood preservatives. Nanotoxicology. 2018. vol. 12, no. 7, pp. 747-765. https://doi.org/10.1080/17435390.2018.1472314.

[19] HOLAN, E. JAVORKOVA, K. VRBOVA, Z. VECERA, P. MIKUSKA, P. COUFALIK, P. KULICH, R. SKOUPY, M. MACHALA, A. ZAJICOVA, P. ROSSNER, A murine model of the effects of inhaled CuO nanoparticles on cells of innate and adaptive immunity - a kinetic study of a continuous three-month exposure. Nanotoxicology. 2019. vol. 13, pp. 952-963. https://doi.org/10.1080/17435390.2019.1602679.

[20] ROSSNEROVA, A., PELClOVA, D., ZDIMAL, V., ROSSNER, P., ELZEINOVA, F., VRBOVA, K., TOPINKA, J., SCHWARZ, J., ONDRACEK, J., KOSTEJN, M., KOMARC, M., VLCKOVA, S., FENCLOVA, Z., DVORACKOVA, S. The repeated cytogenetic analysis of subjects occupationally exposed to nanoparticles: a pilot study. Mutagenesis. 2019. vol. 34, no. 3, pp. 253-263. https://doi.org/10.1093/mutage/gez016.

[21] ROSSNEROVA, A., POKORNA, M., SVECOVA, V., SRAM, R.J., TOPINKA, J., ZÖLZER, F., ROSSNER, P. Adaptation of the human population to the environment: Current knowledge, clues from Czech cytogenetic and "omics" biomonitoring studies and possible mechanisms. Mutat. Res. 2017. vol. 773, pp. 188-203. https://doi.org/10.1016/j.mrrev.2017.07.002. 